\title{
Dynamics of Land Use in the Basin of Ancient Lagoons (Toho, Todougba, Ahouangan, Dati, Djonou) in South Benin from 1990 to 2020 and Their Current Vulnerability to Pollution
}

\author{
Mardochée Ephraïm Achoh ${ }^{*}$, Hyppolite Agadjihouédé1, Luc Gangbè2, Romaric Aïzonou1, \\ Christelle Claudia Akotossodé ${ }^{3}$, Simon Ahouanssou Montcho', Antoine Chikou ${ }^{4}$ \\ ${ }^{1}$ Unit of Aquaculture Research and Fisheries Management, Laboratory of Fisheries and Animal Sciences, National University of \\ Agriculture, Ketou, Benin \\ ${ }^{2}$ National Institute of Agricultural Research of Benin, Cotonou, Benin \\ ${ }^{3}$ Department of Environment and Renewable resources, University of Ibadan, Ibadan, Nigeria \\ ${ }^{4}$ Laboratory of Hydrobiology and Aquaculture (LHA), Faculty of Agronomic Sciences, University of Abomey-Calavi, Cotonou, \\ Benin \\ Email: *mardoachoh12345@gmail.com
}

How to cite this paper: Achoh, M. E., Agadjihouédé, H., Gangbè, L., Aïzonou, R., Akotossodé, C. C., Montcho, S. A., \& Chikou, A. (2021). Dynamics of Land Use in the Basin of Ancient Lagoons (Toho, Todougba, Ahouangan, Dati, Djonou) in South Benin from 1990 to 2020 and Their Current Vulnerability to Pollution. Journal of Geoscience and Environment Protection, 9, $28-45$. https://doi.org/10.4236/gep.2021.911003

Received: September 10, 2021

Accepted: November 13, 2021

Published: November 16, 2021

Copyright (อ 2021 by author(s) and Scientific Research Publishing Inc. This work is licensed under the Creative Commons Attribution International License (CC BY 4.0).

http://creativecommons.org/licenses/by/4.0/ (c) (i) Open Access

\begin{abstract}
The management of living resources and space requires continuous assessments in order to adjust deviations as necessary for sustainable use. It is in this context that the present study was conducted and aims on the one hand to assess the dynamics of land use in the basin of the five-finger lagoons and on the other hand to assess the degree of their vulnerability to organic pollution. Thus, the satellite images were collected in free access on the site http://earthexplorer.usgs.gov/ of the USGS (US Geological Survey) of NASA. Image correction was performed with ENVI 5.1 software and classification was performed with ArcGIS 10.8 software. The degree of vulnerability was evaluated through the weighting of different parameters (slope, land use, type of pass, runoff, and density of the hydrobiological network) by the multi-criteria method of Saaty (Analytic Hierarchy Process Methods) and the application of mapping. It is found that for the dynamics of land use, forests, savannahs and plantations have experienced a significant reduction in their area (respectively $98.9 \%, 99.60 \%$ and $77.10 \%$ ) between 1990 and 2020. As for settlements, water bodies and swamps, they have increased in area to different proportions. The soils are more denuded $(\mathrm{Tc}=1264 \%)$. This makes the living space vulnerable and therefore facilitates the transfer of pollutants to the aquatic environment. The evaluation of the degree of vulnerability to pollution of the lagoons of the basin showed that the Toho-and Todougba lagoons are
\end{abstract}


under a very high degree of vulnerability $(73 \%-100 \%)$ and do not augur well for the living resources. The other lagoons, notably the Dathi and Djonou lagoons, are also under stress from the pressures of surrounding activities. It is therefore important to assess the level of pollution of the Toho and Todougba lagoons through pollution indices in order to make decisions that will allow their sustainable use, especially for aquaculture.

\section{Keywords}

Land Use, Vulnerability, Lagoons, Pollution, Anthropogenic Activity

\section{Introduction}

Wetlands are ecosystems that provide various economic, social and ecological functions directly or indirectly for humanity. They also ensure the physical-chemical and biological regulation of the physical environment, the conservation of biological diversity and constitute a very productive environment on the planet (Akotossode et al., 2018; Nfotabong-Atheull et al., 2013; Onana et al., 2014). However, population growth and its corollaries (land use, agriculture, fish farming, fisheries, need for food security and others) coupled with the effects of climate change (climate disruption and others) constitute permanent stress factors increasingly growing on wetlands (Rao et al., 2007). As a result, the current state of a wetland is highly dependent on how it has been used over the years.

In Benin, the basin of the complex of ancient lagoons still called the five-finger lagoon (including the Toho and Todougba lagoons) is the object of a growing attraction for various activities, such as fish farming in cages, agriculture, tourism (for its ornithological richness) with the development of hotels, places of rest and recreation, and crafts. These activities are likely to create modifications in the functioning of the basin in this case of the aquatic ecosystems which are the final receptacles of the whole drainage network. These modifications can lead to losses of biodiversity, fragmentation of biological habitats (Benayas et al., 2009; Dauda et al., 2014; Yoboue et al., 2018), of pollution (Degefu et al., 2011; Djihouessi et al., 2019) and other impacts that affect the biocenosis. These susceptibilities may be exacerbated by the extent of greenhouse gas production in wetlands (Deemer et al., 2016).

The Toho and Todougba lagoons which constitute the major water body of this basin (Hagemeijer et al., 1997) through the potentialities they offer to fish farming and fishing, are experiencing the beginning of organic pollution (Achoh et al., 2021). Thus, the more degradation pressure there is on the basin, the more organic matter will be exchanged between the different lagoons of the complex, which will be polluted and become unsuitable for aquatic life.

The objective of the present work is to evaluate the effect of anthropogenic pressure on the five-finger lagoon basin over the last thirty years (1990-2020) based on remote sensing and to deduce the current vulnerability to pollution of these lagoons. 


\section{Study Area}

The Ancient Lagoon Basin, also known as the Five Finger Lagoon, is located in the heart of Ramsar Site 1017. It is located between $6^{\circ} 23^{\prime} 34.89^{\prime \prime} \mathrm{N}$ and $2^{\circ} 10^{\prime} 24.97^{\prime \prime} \mathrm{W}$. It is bounded to the north by the commune of Tori-Bossito and Kpomassè, to the south by the commune of Cotonou, to the east by the commune of Abomey-Calavi and to the west by the arrondissement of Pahou (commune of Ouidah). The basin has five lagoons: Toho, Todougba, Ahouangan, Dati and Djonou. In addition to these lagoons, the basin has a vast network of swamps, artificial lakes, flood plains and vegetation consisting of palm groves (Elaeis guineensis), fallow fields, savannah and classified forest (Hagemeijer et al., 1997). Several activities are carried out in the area, including agriculture, fishing, aquaculture, livestock, market gardening, handicrafts and hotel and restaurant activities.

The Toho and Todougba lagoons constitute the major ecosystems of this basin and are therefore very attractive for cage fish farming (Aïzonou et al., 2019) and other activities, particularly tourism. The communication between the different arms of the aquatic ecosystems of the basin conditions the exchange of dissolved matter. The descriptions of the study environment are presented in Figure 1 and Figure 2.

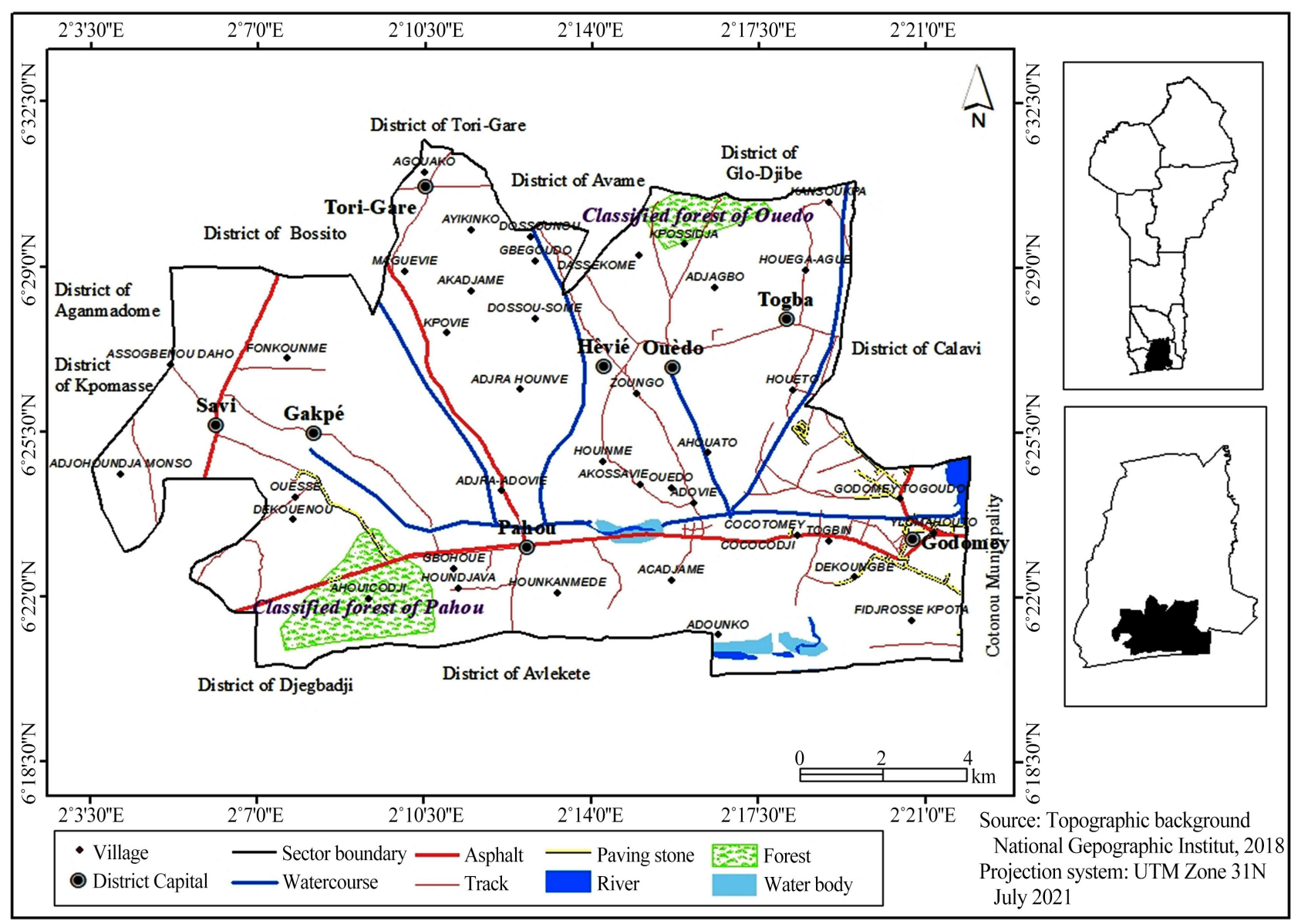

Figure 1. Map of the study area. 


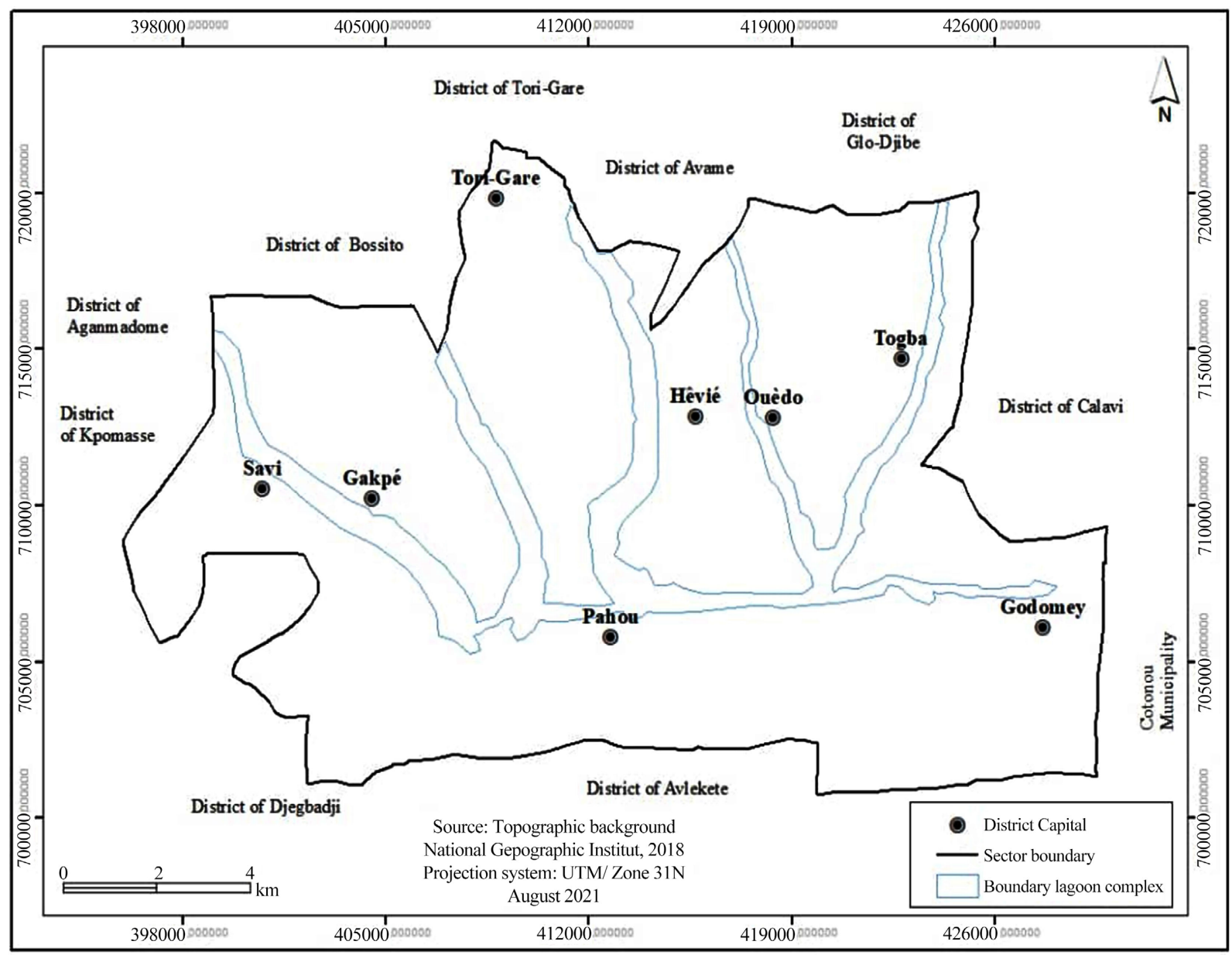

Figure 2. Map showing the five lagoons in the study area.

\section{Methods of Data Collection and Processing}

\subsection{Data Collection}

The images used in this study were extracted by the Global Visualization Viewer on the site https://earthexplorer.usgs.gov/ of the USGS (US Geological Survey) of NASA. They were obtained on different satellites (Landsat 5 TM, Landsat 7 TM, Landsat ETM +, Landsat OLI-TIRS) whose specifications are summarized in Table 1.

\subsection{Land Use Classification}

Using ArcGIS 10.8 software, the maximum likelihood classification algorithm was used to classify the four satellite images. The land cover classification was performed using the supervised classification method using ENVI 5.1 software. Nine (09) land cover classes (Bare soil, dense forest, Open forest, Swamp, Savannah, Plantation, Water body, Fields and fallows, Agglomeration) were found in the study area. According to the years, the obtained Kappa coefficients are respectively $0.9779,0.9583,0.9777$ and 0.9901 for the years 1990, 2000, 2010 and 2020. The values obtained for the Kappa coefficient are all significantly close to 
Table 1. Specification of the satellites used.

\begin{tabular}{rcccc}
\hline Date of acquisition & Satellite Sensor & Resolution & Path /Row & Format \\
\hline 13/01/1990 & Landsat 5 TM & $30 \mathrm{~m}$ & $192 / 055$ & GeoTIFF \\
$13 / 12 / 2000$ & Landsat 7 TM & $30 \mathrm{~m}$ & $192 / 055$ & GeoTIFF \\
03/12/2010 & Landsat ETM + & $30 \mathrm{~m}$ & $192 / 055$ & GeoTIFF \\
$23 / 12 / 2020$ & Landsat OLI-TIRS & $30 \mathrm{~m}$ & $192 / 055$ & GeoTIFF \\
\hline
\end{tabular}

the value " 1 " and testify that the classification performed strongly reflects the realities of the field. The rate of change (Tc) of land cover in a given period was calculated by applying the formula used by Toyi et al. (2013).

$$
\mathrm{Tc}=\frac{\mathrm{SA} 2-\mathrm{SA} 1}{\mathrm{SA} 1} \times 100
$$

With SA1 and SA2 the initial and final areas of the land use class. When Tc has a positive value, it indicates progressions of area at the level of the class; in the opposite case, it indicates losses of area

\subsection{Assessment of Vulnerability to Pollution of Lagoons}

The vulnerability of a surface water to pollution depends on several parameters including slope, soil type, land use, runoff, density of the watershed network (Ake et al., 2020; Ake et al., 2019; Anoh et al., 2012, 2018; Macary et al., 2010). Based on different works done, the vulnerability assessment was done in three steps namely: identification, classification and assignment of scores to the different parameters; determination of the weighting coefficient by the multi-criteria method of Saaty (1977) (Analytic Hierarchy Process Methods) and application of mapping for vulnerability assessment.

\subsubsection{Identification, Classification and Assignment of Notes to the Different Parameters}

Slope: The slope map was made after processing a map of the Digital Elevation Model (DEM) of the basin with ArcGIS 10.8. Then, the classification was made with the module "3D analysis tool" of the same software and obtained six (6) classes ranging from $0 \%$ to $6.99671 \%$ and presented in Figure 3.

Soil type: The soil map of the study area was obtained from the soil profile of Benin. The area has three main soil categories (Figure 4), namely

- Highly depleted ferralitic soils

- Ferralitic soils that are strongly rejuvenated

- Ferruginous soils

Annual runoff: Runoff was determined using the Thornthwaite method. It was determined by multiplying the runoff coefficient by the average annual rainfall for the last ten years. Let $\mathrm{R}$ be the annual runoff $(\mathrm{mm})$, $\alpha$ runoff coefficient (\%) and $\mathrm{Pa}$ the annual rainfall $(\mathrm{mm})$.

$$
R=\alpha \times P
$$




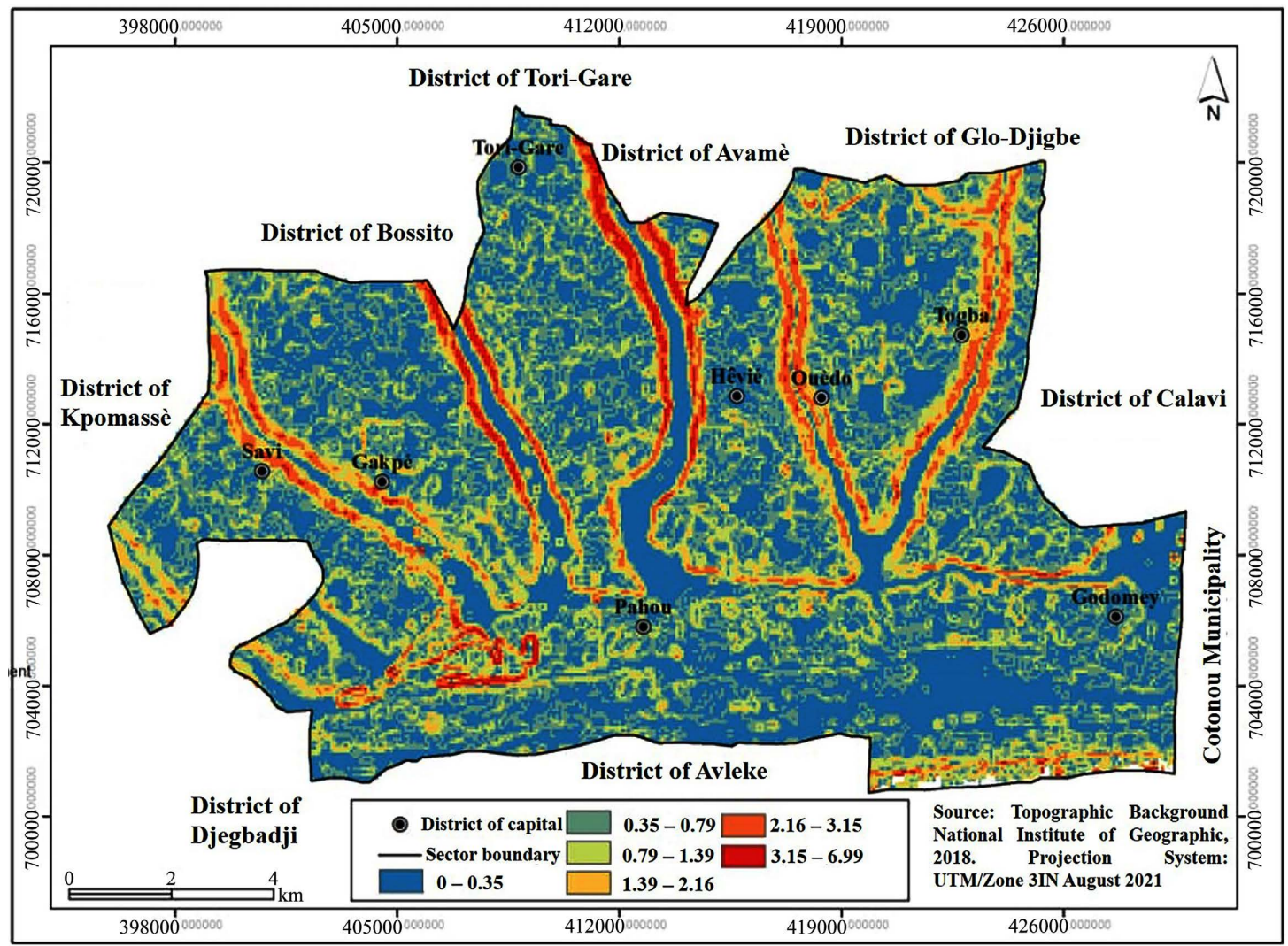

Figure 3. Slope classification image.

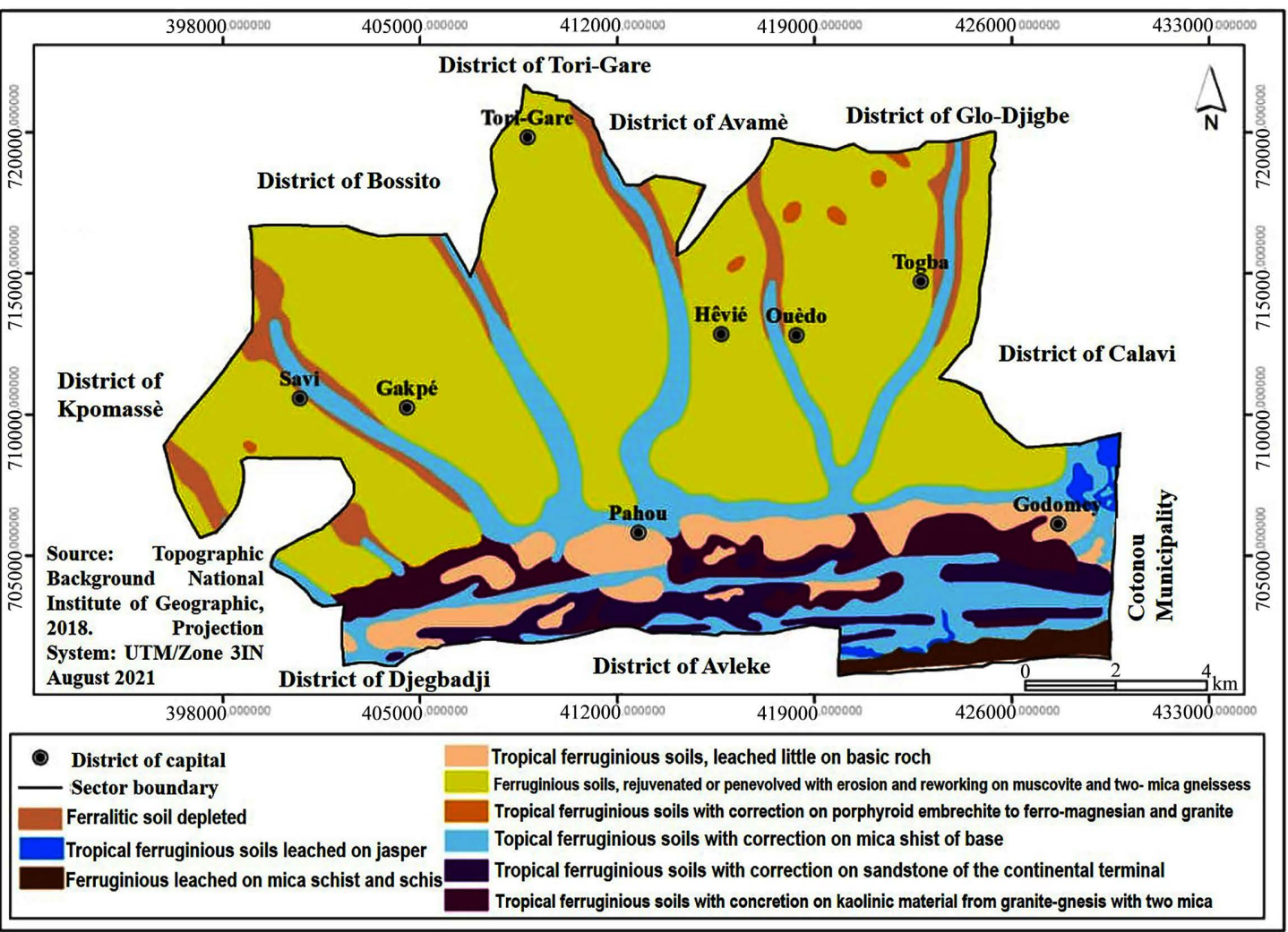

Figure 4. Soil type classification image. 
The runoff coefficient for Benin, the former Dahomey is 69\% (Roose, 1973; Roose \& Lelong, 1976). The average annual rainfall obtained from the Water Directorate is $1200 \mathrm{~mm} \cdot \mathrm{an}^{-1}$. Thus, the calculated annual runoff is: $\mathrm{R}=828 \mathrm{~mm}$. This factor has only one class with a rating of 3 .

Density of the hydrographic network: The density of drainage was obtained by making the map from the "line-density" tool of the ArcGis software. The density varies between -6 and $44 \mathrm{~km}$. The mapping of the parameters was followed by a reclassification of the different values of these five parameters based on the work of Schoen and Codvelle (2001) and allowed to represent the classification maps of the said parameters from the tool "Reclassify" of the module "Spatial Analyst" under ArcGis before their weighting. The classification resulted in six (6) classes namely [-6 - 0]; [0 - 8.8]; [8.8 - 17.6]; [17.6 - 26.4]; [26.4 35.2]; [34.2 - 44] as presented in Figure 5.

\subsubsection{Scoring of the Different Parameters Classes}

The assignment of scores to the different classes of parameters was inspired by the work of Schoen \& Codvelle (2001) on the vulnerability of surface waters. Thus, the scores assigned vary from 1 to 4 , taking into account the importance of the different parameters of vulnerability to pollution of the ecosystems studied. Table 2 shows the scores assigned to the different classes of vulnerability parameters.

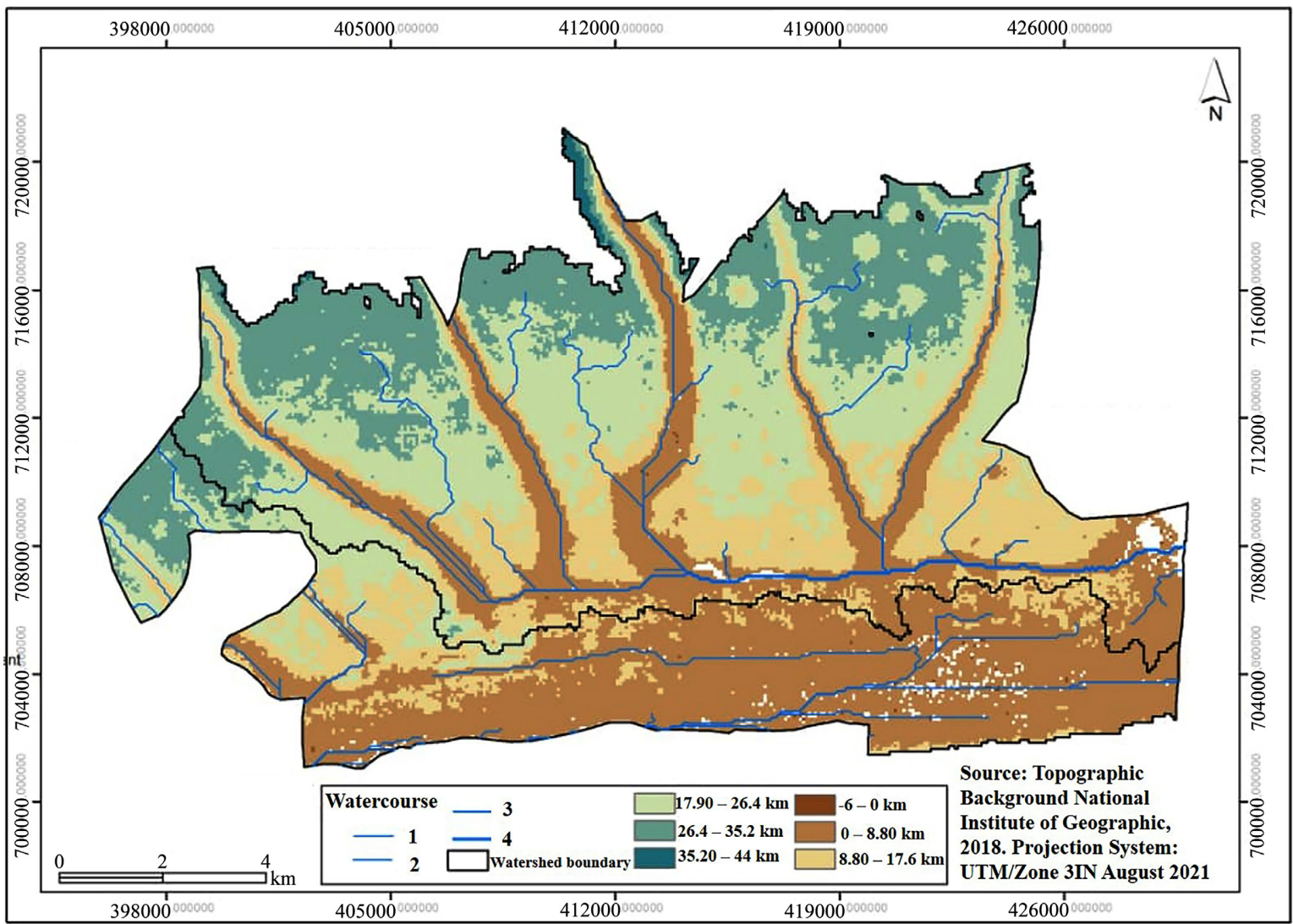

Figure 5. Map of the basin's hydrographic network. 
Table 2. Scoring of the vulnerability parameter classes.

\begin{tabular}{|c|c|c|}
\hline Parameters & Classes & Notes \\
\hline \multirow{6}{*}{ Slope (\%) } & $0-0.35$ & 1 \\
\hline & $0.35-0.79$ & 1 \\
\hline & $0.79-1.39$ & 2 \\
\hline & $1.39-2.16$ & 3 \\
\hline & $2.16-3.15$ & 3 \\
\hline & $3.15-6.99$ & 4 \\
\hline \multirow{3}{*}{ Soil type } & Highly depleted ferralitic soils & 1 \\
\hline & Ferralitic soils that are strongly rejuvenated & 2 \\
\hline & Ferruginous soils & 2 \\
\hline \multirow{9}{*}{ Land use } & Dense forest & 1 \\
\hline & Clear forest & 1 \\
\hline & Swamp & 1 \\
\hline & Savannah & 1 \\
\hline & Waters bodies & 2 \\
\hline & Bare ground & 3 \\
\hline & Planting & 3 \\
\hline & Field and fallow land & 3 \\
\hline & Agglomerations & 4 \\
\hline Runoff (mm) & 828 & 3 \\
\hline \multirow{6}{*}{$\begin{array}{c}\text { Density of the } \\
\text { drainage network }\end{array}$} & $-6-0 \mathrm{~km}$ & 1 \\
\hline & $0-8.8 \mathrm{~km}$ & 2 \\
\hline & $8.80-17.6 \mathrm{~km}$ & 2 \\
\hline & $17.6-26.4 \mathrm{~km}$ & 3 \\
\hline & $26.60-35.2 \mathrm{~km}$ & 3 \\
\hline & $35.20-44 \mathrm{~km}$ & 4 \\
\hline
\end{tabular}

\subsubsection{Weighting of the Different Classes of Parameters by Saaty's} Multicriteria Method

The multicriteria method AHP (Analytic Hierarchy Process) of (Saaty, 1977) was used for the weighting of the parameters and is summarized in two steps, namely the realization of the binary combinations and the development of the priority matrices.

Realization of the binary combinations: For the binary combination, the parameters were compared two by two according to their level of importance. These comparisons lead to the constitution of reciprocal square matrices. According to this comparison, when two parameters have the same importance, the method (Saaty, 1977) requires that the value of " 1 " be assigned to both parameters. When one parameter is more important than the other, it takes a higher value between 1 and 10; the other takes the inverse of this value. This method 
produces standardized weights that sum to " 1 ". The matrix resulting from the pairwise comparison of the different parameters is summarized in Table 3.

Determination of the weighting coefficients: The weighting coefficient (WC) of a parameter corresponds to its level of involvement in the vulnerability to pollution of the aquatic ecosystem studied. It is determined in two steps: the determination of the Eigenvector noted $(\mathrm{Vp})$ and the calculation of the weighting coefficient $(\mathrm{Cp})$.

The formula for determining the eigenvector is:

$$
\mathrm{Vp}=\sqrt[n]{a_{1} \times a_{2} \times a_{3} \times \cdots \times a_{n}}
$$

With $n=$ the total number of parameters compared and $a_{1}, a_{2}, a_{3}, \ldots, a_{n}$ the different values attributed to the parameters during the comparison.

As for the weighting coefficient $(\mathrm{Cp})$, it is calculated by the following formula:

$$
\mathrm{Cp}=\frac{\mathrm{Vp}}{\sum \mathrm{Vp}}=\frac{\mathrm{Vp}}{\mathrm{Vp}_{1}+\mathrm{Vp}_{2}+\mathrm{Vp}_{3}+\cdots+\mathrm{Vp}_{n}}
$$

With Vp the eigenvector of the parameter for which the coefficient $\mathrm{Cp}$ wants to be calculated and $\mathrm{Vp}_{1}, \mathrm{Vp}_{2}, \mathrm{Vp}_{3}, \ldots, \mathrm{Vp}_{n}$ the different eigenvectors for each parameter. Note that the sum of the weighting coefficients of all parameters must be equal to 1 .

Coherence Ratio (CR) of the matrix: The Coherence Ratio allows validating the coherence of the comparison matrix. This ratio defines the probability that the comparison matrix is randomly constituted. According to Saaty (1980), The matrix is consistent when $\mathrm{CR} \leq 10 \%$. It is inconsistent when of CR $>10 \%$ scale, the matrix is coherent when the $\mathrm{CR}$ ratio $\leq 10 \%$. It is incoherent when of CR $>$ $10 \%$. The consistency ratio $(\mathrm{CR})$ is determined by the following formula:

$$
\mathrm{CR}=\frac{\mathrm{CI}}{\mathrm{RI}}
$$

With RI the random index and CI the consistency index.

The values of the random index are a function of the number of vulnerability parameters compared (Saaty, 1977). Considering the number of parameters compared in this study which is 5, the value of RI is 1.12 (Saaty, 1977).

Table 3. Comparison matrix of vulnerability parameters.

\begin{tabular}{cccccc}
\hline & P & TS & OS & R & D \\
\hline P & 1 & 3 & 3 & 5 & 7 \\
TS & $1 / 3$ & 1 & 3 & 4 & 5 \\
OS & $1 / 3$ & $1 / 3$ & 1 & 2 & 3 \\
R & $1 / 5$ & $1 / 4$ & $1 / 2$ & 1 & 2 \\
D & $1 / 7$ & $1 / 5$ & $1 / 3$ & $1 / 2$ & 1 \\
Total & 2.010 & 4.783 & 7.833 & 12.5 & 18 \\
\hline
\end{tabular}

$\mathrm{P}=$ Slope; TS = Soil Type; OS = Soil Occupation; $\mathrm{R}=$ Runoff; $\mathrm{D}=$ Density of the hydrographic network. 
As for the value of the consistency index (CI), it is determined by the following formula:

$$
\mathrm{CI}=\frac{\lambda \max -k}{k-1}
$$

With $\lambda \max$ the average of the rational priorities and $k$ the number of parameters compared.

The average of the rational priorities $(\lambda \max )$ is computed through a few key steps namely:

- Normalization of the original matrix by dividing each value of a given column by the sum of the values of that column;

- Determination of the priority vector [C] by averaging each row;

- Determination of the global priority [D] by summing the product of each value of the matrix by the priority vector of the corresponding parameter;

- Determination of the rational priority [E] by dividing each global priority by the corresponding priority vector;

- Determination of the average of the rational priorities $(\lambda \max )$ by the formula

$$
\lambda \max =\frac{[\mathrm{E}]}{k}
$$

Table 4 summarizes the different calculations performed to determine the coherence index.

The CR Consistency ratio is less than 10\% (0.23\%), the assigned judgments are good to better express the vulnerability of the basin to pollution.

\subsection{Vulnerability Assessment}

The vulnerability index (Iv) is obtained from the following formula:

$$
\mathrm{Iv}=(0.3283 \times \mathrm{P})+(0.2492 \times \mathrm{O})+(0.1773 \times \mathrm{S})+(0.1368 \times \mathrm{R})+(0.1082 \times \mathrm{D})
$$

From the vulnerability index, the classification map was made and obtained six (06) classes between 0.23 and 21.80. The conversion of the classes obtained into percentages was done using the method used by Jourda et al. (2007). This conversion allows a better understanding of the degree of vulnerability. The

Table 4. Different calculations to determine the CI and CR.

\begin{tabular}{ccccccccccccccc}
\hline & $\mathbf{P}$ & TS & OS & $\mathbf{R}$ & $\mathrm{D}$ & $\mathrm{Vp}$ & $\mathrm{Cp}$ & {$[\mathrm{A}]$} & {$[\mathrm{C}]$} & {$[\mathrm{D}]$} & {$[\mathrm{E}]$} & $\lambda \max$ & $\mathrm{CI}$ & $\mathrm{CR}$ \\
\hline $\mathbf{P}$ & 0.498 & 0.627 & 0.383 & 0.400 & 0.389 & 2.297 & 0.459 & 2.297 & 5.008 & 2.297 & 0.459 & & \\
TS & 0.166 & 0.209 & 0.383 & 0.320 & 0.278 & 1.356 & 0.271 & 1.356 & 5.017 & 1.356 & 0.271 & & \\
OS & 0.166 & 0.070 & 0.128 & 0.160 & 0.167 & 0.690 & 0.138 & 0.690 & 5.004 & 0.690 & 0.138 & & \\
R & 0.100 & 0.052 & 0.064 & 0.080 & 0.111 & 0.407 & 0.081 & 0.407 & 5.043 & 0.407 & 0.081 & & \\
D & 0.071 & 0.042 & 0.043 & 0.040 & 0.056 & 0.251 & 0.050 & 0.251 & 4.980 & 0.251 & 0.050 & & \\
$\mathbf{\Sigma}$ & 1.000 & 1.000 & 1.000 & 1.000 & 1.00 & 5.000 & 1.000 & 5.000 & 25.051 & 5.000 & 1.000 & & & \\
\hline
\end{tabular}

$\mathrm{P}=$ Slope TS = Soil Type; OS = Soil Occupation; $\mathrm{R}=$ Runoff; $\mathrm{D}=$ Density of the hydrographic network. 
conversion of the indices into percentages is calculated from the following formula:

$$
\mathrm{Iv}=\frac{(\mathrm{Ii}-\mathrm{Imin})}{(\operatorname{Imax}-\operatorname{Imin})} \times 100
$$

With Ii $=$ index to be identified, $\operatorname{Imax}=$ the maximum index $(21.80)$ and Imin $=$ the minimum index $(0.23)$

\section{Results}

The diachronic study of land use in the basin of ancient lagoons (Toho, Todougba, Ahouangan, Dati, Djonou) carried out over the last thirty years (1990-2020) revealed significant variations in time and space (Figure 6). Indeed, nine (09) classes were defined from the classification carried out by 10-year intervals. This classification proved to be very significant according to the Kappa index, which is of the order of 0.9 for all the treatments carried out, testifying to the convergence between the field data and the satellite data.

From the analysis of the data obtained (Table 5 and Table 6), it appears that over the last thirty years (1990-2020), the area of dense forests, open forests, savannahs and plantations have significantly decreased by $98.93 \%, 100 \%, 99.60 \%$ and $77.10 \%$ respectively. On the other hand, the other classes, notably bare soil, settlements, fields and fallow land, swamps and water bodies have recorded a significant increase in their surface area. Thus, the soils are completely bare (Tc $=1264 \%)$, the settlements are more erected $(\mathrm{Tc}=364 \%)$. The water bodies and swamps have extended their bed further with respective rates of change of $23.33 \%$ and $54.18 \%$.

From the above, we can see that the surface area of water bodies and swamps has increased over the last thirty years, as well as that of bare land and settlements, while the surface area of forests, savannahs and plantations has decreased.

Index and degree of vulnerability of the lagoons of the basin to pollution

The different classes obtained from the vulnerability index map vary from [0.23 - 4.89] to [18.50 - 21.80] with 0.23 and 21.80 being the minimum and maximum values respectively. From the analysis of the vulnerability index map (Figure 7) and Table 7, it appears that, with the exception of the coastal zone, high degrees of vulnerability (73\% to 100\%) are observed in the first two arms of the complex, notably the Toho and Todougba lagoons, and in a few surrounding pockets. The Ahouangan lagoon, which is the third arm, also recorded pockets of high vulnerability. For the Dathi and Djonou lagoons, high degrees of vulnerability are observed in the vicinity of the two water bodies.

\section{Discussion}

Land use reveals variations in time and space over a given area. In the basin of the ancient lagoons, there has been a sharp increase in the area of bare land at the expense of forests, savannahs and plantations. Settlements too have seen a 


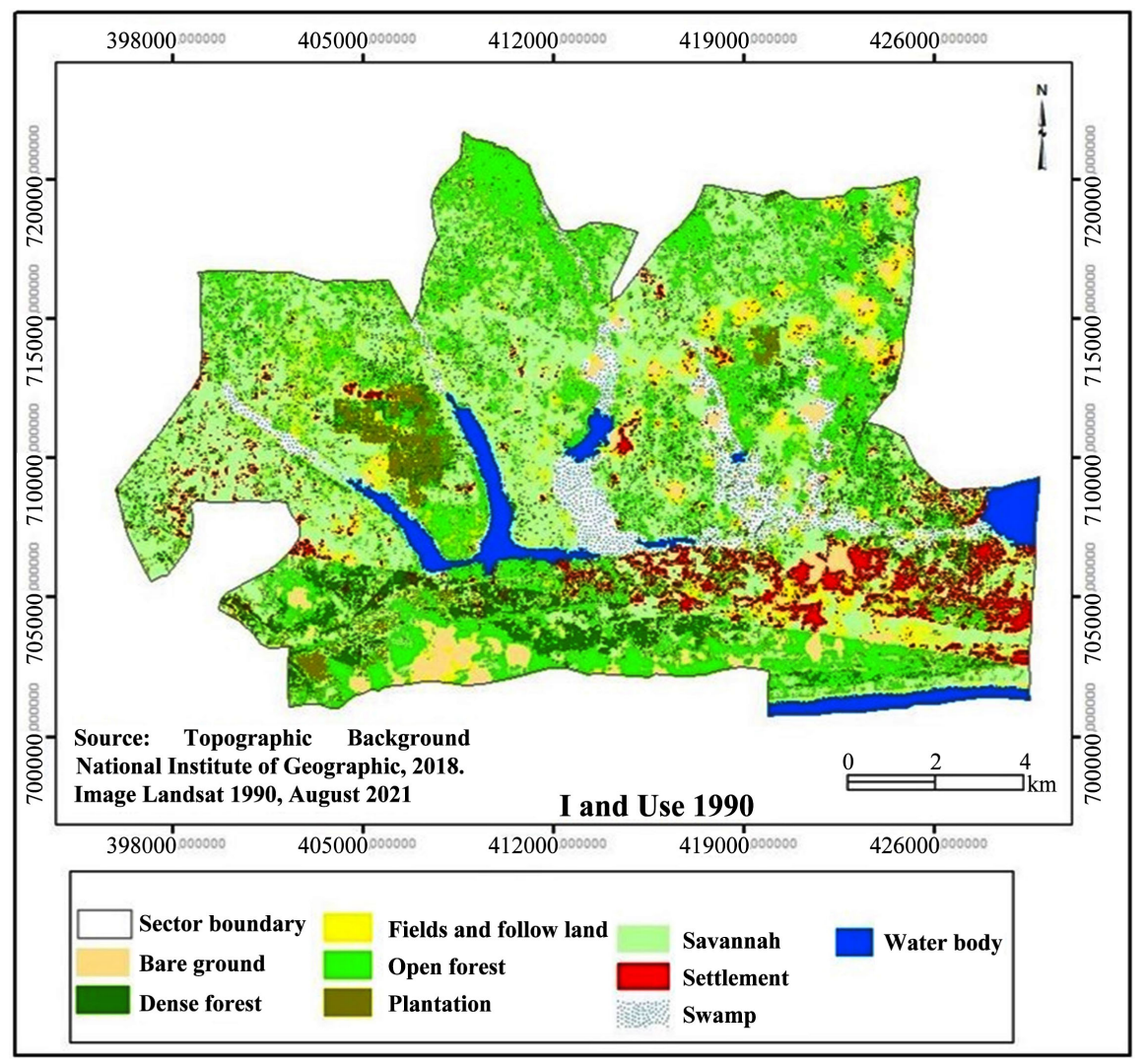

(a)

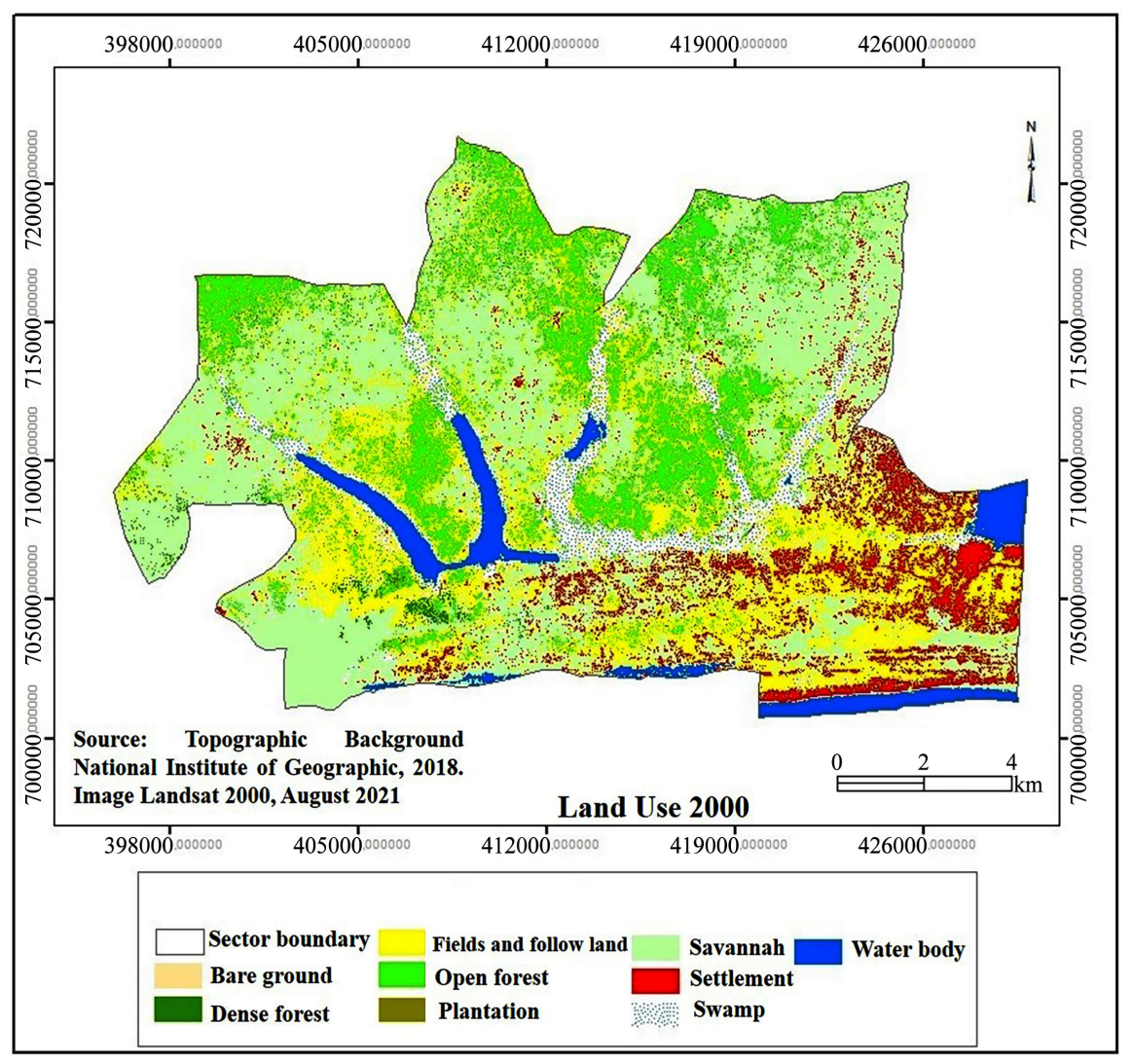

(b) 


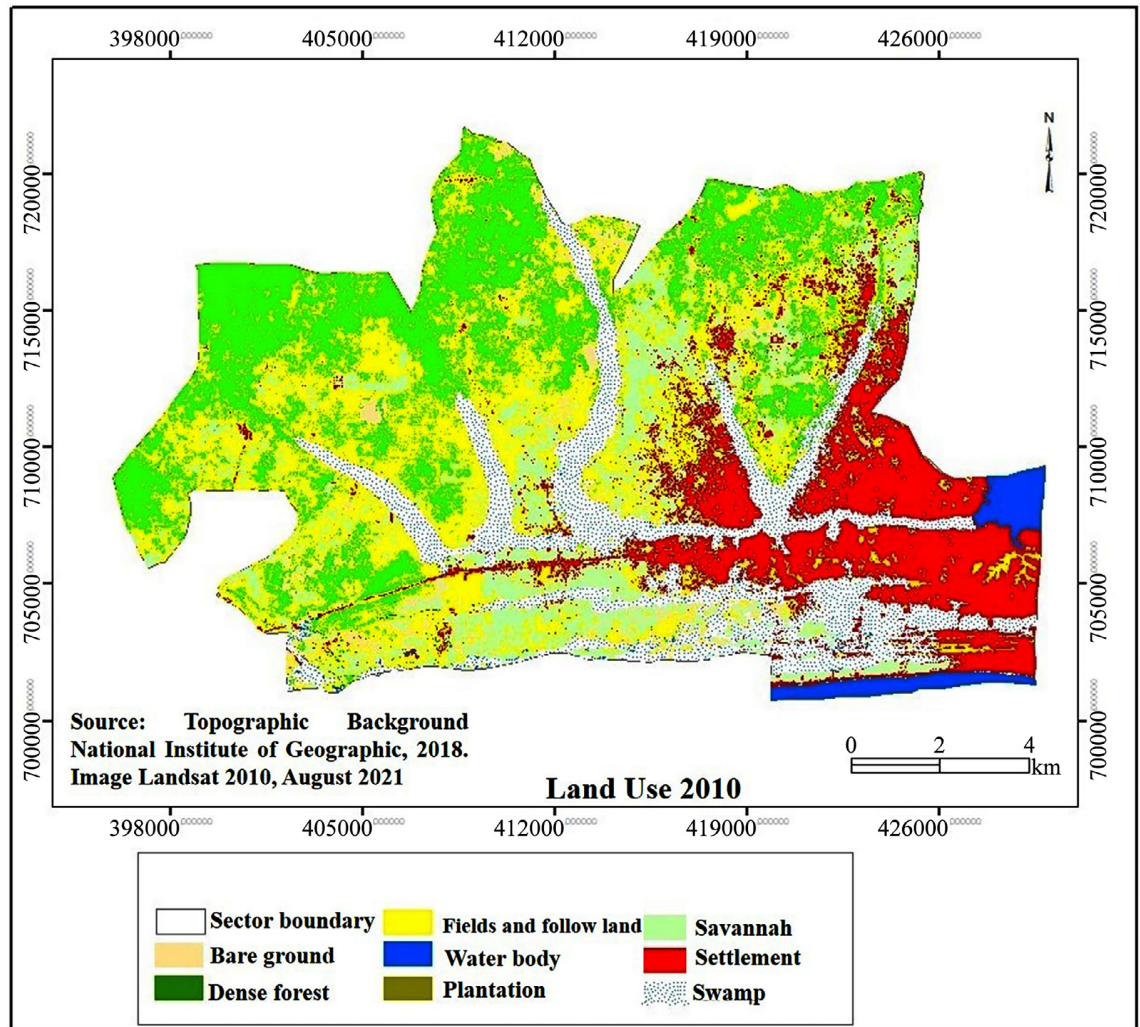

(c)

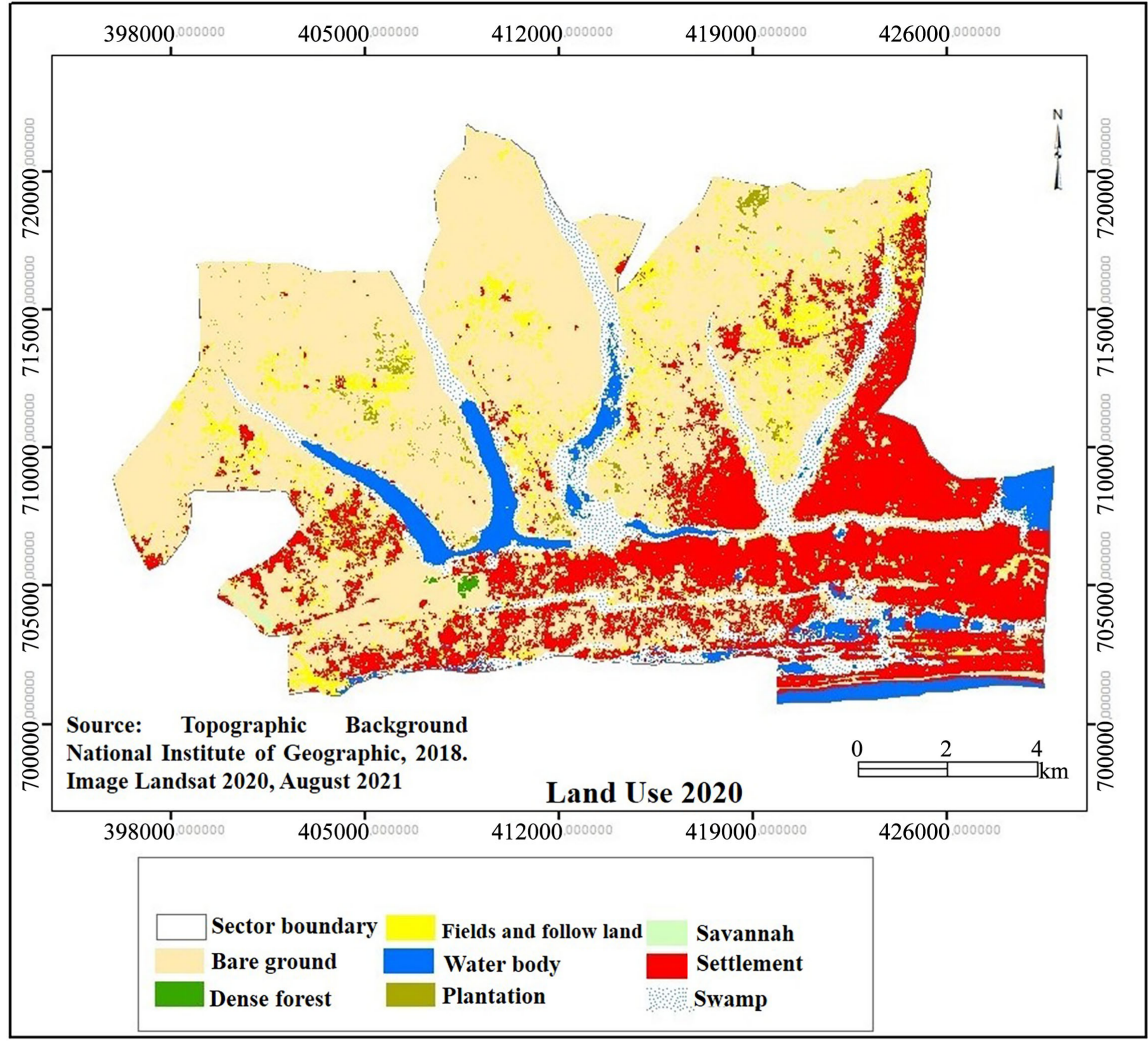

(d)

Figure 6. Land use $((a)=1990,(b)=2000,(c)=2010$ and $(d)=2020)$. 
Table 5. Land area and percentage of land use from 1990 to 2020.

\begin{tabular}{ccccccccc}
\hline & \multicolumn{2}{c}{1990} & \multicolumn{2}{c}{2000} & \multicolumn{2}{c}{2010} & \multicolumn{2}{c}{2020} \\
\cline { 2 - 8 } & Area (ha) & (\%) & Area (ha) & (\%) & Area (ha) & (\%) & Area (ha) & (\%) \\
\hline Dense forest & 1848.847 & 3.957 & 1889.057 & 4.081 & 1889.057 & 4.081 & $25,217.732$ & 54.472 \\
Clear forest & 4133.700 & 8.848 & 16.783 & 0.036 & 16.783 & 0.036 & 44.190 & 0.095 \\
Swamp & 9868.901 & 21.124 & 9805.177 & 21.180 & 9805.177 & 21.180 & 0.000 & 0.000 \\
Savannah & 2658.620 & 5.691 & 6837.946 & 14.771 & 6837.946 & 14.771 & 4099.112 & 8.854 \\
Waters bodies & $19,646.997$ & 42.054 & 6753.686 & 14.589 & 6753.686 & 14.589 & 78.849 & 0.170 \\
Bare ground & 1935.491 & 4.143 & 0.090 & 0.000 & 1083.620 & 2.341 & 2387.002 & 5.156 \\
Planting & 2872.594 & 6.149 & 1083.620 & 2.341 & $12,568.555$ & 27.149 & 3067.926 & 6.627 \\
Field and fallow land & 2389.250 & 5.114 & $12,568.555$ & 27.149 & 7339.506 & 15.854 & $11,087.251$ & 23.949 \\
Agglomerations & 1364.314 & 2.920 & 7339.506 & 15.854 & 0.090 & 0.000 & 312.370 & 0.675 \\
Total & $46,718.714$ & 100.000 & $46,294.420$ & 100.000 & $46,294.420$ & 100.000 & $46,294.432$ & 100.000 \\
\hline
\end{tabular}

Table 6. Percentage change in land cover by time interval.

\begin{tabular}{ccccc}
\hline & \multicolumn{4}{c}{ Land Use variation (\%) } \\
\cline { 2 - 5 } & $1990-2000$ & $2000-2010$ & $2010-2020$ & $1990-2020$ \\
\hline Dense forest & 2.17 & 0.00 & 1234.94 & 1263.97 \\
Clear forest & -99.59 & 0.00 & 163.30 & -98.93 \\
Swamp & -0.65 & 0.00 & -100.00 & -100.00 \\
Savannah & 157.20 & 0.00 & -40.05 & 54.18 \\
Waters bodies & -65.62 & 0.00 & -98.83 & -99.60 \\
Bare ground & -100.00 & $1,203,922.22$ & 120.28 & 23.33 \\
Planting & -62.28 & 1059.87 & -75.59 & 6.80 \\
Field and fallow land & 426.05 & -41.60 & 51.06 & 364.05 \\
Agglomerations & 437.96 & -100.00 & $346,977.78$ & -77.10 \\
\hline
\end{tabular}

Table 7. Class of vulnerability indices and degree of vulnerability.

\begin{tabular}{ccc}
\hline $\begin{array}{c}\text { Vulnerability } \\
\text { Index Classes (Iv) }\end{array}$ & $\begin{array}{c}\text { Percentage corresponding } \\
\text { to each index }\end{array}$ & $\begin{array}{c}\text { Class Degree of } \\
\text { vulnerability }\end{array}$ \\
\hline $0.23-4.89$ & $0-21.60$ & Very low \\
$4.89-8.18$ & $21.60-36.86$ & Very low \\
$8.18-10.64$ & $36.86-48.26$ & Low \\
$10.64-16.13$ & $48.26-73.71$ & Medium \\
$16.13-18.50$ & $73.71-84.70$ & High \\
$18.50-21.80$ & $84.70-100$ & Very High \\
\hline
\end{tabular}




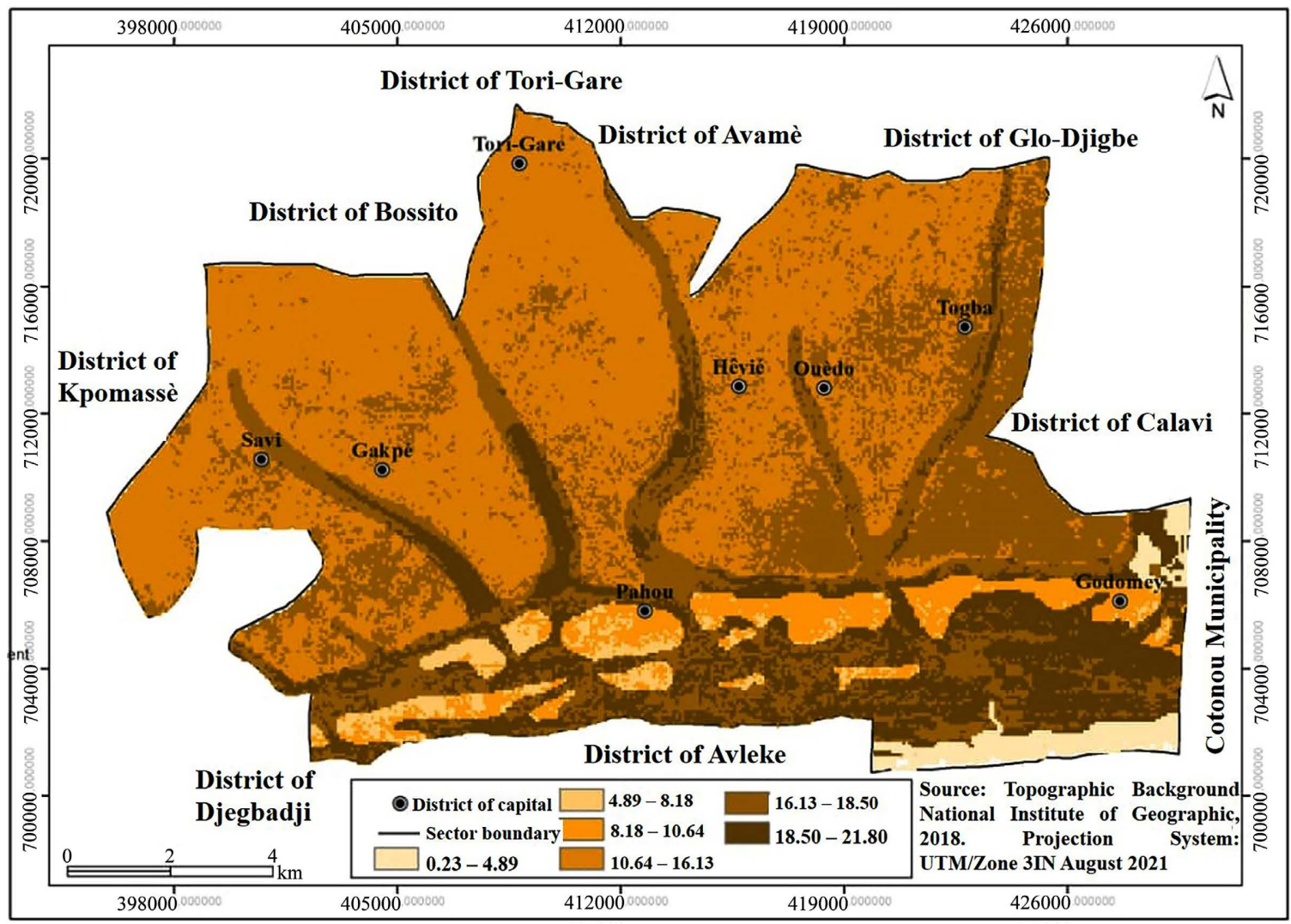

Figure 7. Basin vulnerability index.

sharp increase; this is a response to the continuous search for living space by humans especially in the current context of rampant demography (Akotossode et al., 2018). Although the area of water bodies has seen a sawtooth variation over the last thirty years in the basin, the factor to which they are more vulnerable is pollution. Indeed, the impacts of the destruction of vegetation and the occupation of space by urban areas are felt in terms of organic pollution of aquatic ecosystems in the basin. This is shown in the work of Achoh et al. (2021) which reveals the pollution of the Toho and Todougba lagoons (two major lagoons in the basin) through the evaluation of indices. Thus, the more pressure there is on the occupation of space by humans, the greater the production of organic matter and the more polluted the ecosystems of the basin will be.

The evaluation of the vulnerability of the lagoons to organic pollution was carried out in order to detect areas of high pressure on the aquatic ecosystems of the basin. The results obtained on the degree of vulnerability, particularly on the first two arms of the lagoons (Toho and Todougba lagoons), show that the two ecosystems are highly vulnerable to organic pollution ( $73 \%$ to $100 \%)$. This very high degree of vulnerability is related to the strong pressure exerted on these two lagoons through various activities, including mainly cage aquaculture, which provides more than $50 \%$ of the total quantity of fish farmed and marketed in the Republic of Benin (DPH/MAEP, 2019). Pollution indicators were revealed in this session of the basin by Capo-Chichi et al. (2018) who had noticed an abun- 
dance of macroinvertebrates associated with organic-rich environments. Yoboue et al. (2018) also reported that cage aquaculture is a source of organic pollution. Therefore, the development of cage aquaculture on Toho and Todougba lagoons explains the high degree of vulnerability observed. For the other arms, the high vulnerability in the vicinity is related to the high land occupation especially in 2020 where the percentage of land occupation by settlements between 1990 and 2020 is $364.05 \%$ while forests and savannahs tend to disappear completely.

\section{Conclusion}

The land use dynamics of the Five Fingers Lagoon Basin revealed that forests and savannahs have drastically reduced in area at the expense of settlements and other factors between 1990 and 2020. With population growth and the vital needs of humans, this dynamic has a significant effect on the degree of vulnerability to pollution of the lagoons in the basin. Thus, the Toho and Todougba lagoons, which are under the influence of cage fish farming, recognized as a major source of organic pollution, are subject to a very high degree of vulnerability to pollution. It is necessary to evaluate the pollution indices in these two ecosystems of the basin which are heavily exploited in order to propose measures for a sustainable use. Finally, we suggest that an authorization for the installation of fish farmers on the lagoon should be established and made mandatory in order to better control the flow of organic matter due to fish farming. It is then necessary to determine with rigor, the carrying capacity of the two lagoons in order to have a look on the intensity of production to better control the flow of organic matter related to the fish feeding. It will still be useful to recommend a single type of feed to be used throughout the ecosystem in order to avoid disparities in the contribution of polluting factors, such as phosphorus and nitrogen. It is also advisable to pay attention to the space occupation flow in order to curb as much as possible the collateral anthropic impact.

\section{Acknowledgements}

The authors thank the various readers who evaluated the manuscript for publication.

\section{Conflicts of Interest}

The authors declare no conflicts of interest regarding the publication of this paper.

\section{References}

Achoh, M. E., Agadjihouedé, H., Gangbé, L., Houssou, A., Aïzonou, R., Ahouansou Montcho, S., \& Chikou, A. (2021). Ecological Status of a West African Lagoon Complex under Anthropogenic Pressure, Toho-Todougba Complex, Benin. International Journal of Aquatic Biology. (In Press)

Aïzonou, R., Achoh, M. E., \& Agadjihouèdé, H. (2019). Analysis of Practice of Cage Aquaculture System in TohoTodougba Lagoon, Southern Benin (West Africa). Aquacul- 
ture Studies, 19, 113-123. https://doi.org/10.4194/2618-6381-v19 204

Ake, G. E., Eba, A. E. L., Assi, J. J., Kouadio, B. H., \& Biemi, J. (2019). Apport des SIG a la délimitation des périmètres de protection autour de la prise d'eau de la SODECI à Aboisso, sud-Est de la Côte d'Ivoire. Afrique SCIENCE, 15, 234-252.

Ake, G. E., Eba, A. E. L., Ble, L. O., Adebayo, A., Assi, J. J., Saley, M. B., \& Biemi, J. (2020). Contribution of Geomatics to the Delimitation of Protection Perimeters : Case of Agbo River in Agboville (South-East of Caost d'Ivoire). Journal of Environmental Protection, 11, 470-490. https://doi.org/10.4236/jep.2020.116028

Akotossode, C. C., Achoh, M. E., Agadjihouèdé, H., Vodougnon, H. B., Amandou, S., \& Tchabi, V. (2018). Etat des ressources naturelles de Djegbadji et de Adounko (site Ramsar 1017) au sud Bénin (Afrique de l'Ouest) dans le conexte actuel de changement climatique. Journal de Recherche Scientifiques de l'Université de Lomé (Togo), 20, 19-33.

Anoh, K. A., Jourda, J. P., Kouame, K. J., Koua, T. J.-J., Eba, A. E., \& Lazar, G. (2012). Demarcation of Protection Perimeters for Surface Waters of Taabo (IVORY COAST) Watershed Using GIS and Multicriteria Analysis. Environmental Engineering and Management Journal, 11, 2123-2131. https://doi.org/10.30638/eemj.2012.264

Anoh, K. A., Koua, T. J.-J., Eblin, S. G., Koudou, A., Kouamé, K. J., \& Jourda, J. P. (2018). Catographie de la vulnérabilité intrinsèque des eaux de surface du bassin versant du lac de Taabo en Côte d'Ivoire aux flux diffus de Phosphore. Revue Ivoirienne des Sciences Technologiques, 32, 131-152.

Benayas, J. M. R., Newton, A. C., Diaz, A., \& Bullock, J. M. (2009). Enhancement of Biodiversity and Ecosystem Services by Ecological Restoration : A Meta-Analysis. Science, 325, 1121-1124. https://doi.org/10.1126/science.1172460

Capo-Chichi, H. B. P., Adandédjan, D., Adandédjan, H. A., \& Houélomè, M. A. (2018). Diversité des macro-invertébrés benthiques du complexe lagunaire TohoTodougba au Sud-Ouest du Bénin. In H. B. P. Capo-Chichi, D. Adandédjan, H. Agadjihouèdé, M. T. Agblonon Houélomè, \& P. A. Lalèyè (Eds.), Bulletin de la Recherche Agronomique du Bénin (BRAB, Numéro Spécial Développement Agricole Durable (DAD) (pp. 12-23). Institut National des Recherches Agricoles du Bénin.

Dauda, A. B., Yakubu, S. O., \& Oke, A. O. (2014). Curbing the Menace of Prolific Breeding in "Aquatic Chicken" (Tilapia): A Way out to Improve Fish Production in Nigeria. New York Science Journal, 7, 112-118.

Deemer, B. R., Harrison, J. A., Li, S., Beaulieu, J. J., Del Sontro, T., Barros, N., Bezerra-Neto, J. F., Powers, S. M., Dos Santos, M. A., \& Vonk, J. A. (2016). Greenhouse Gas Emissions from Reservoir Water Surfaces: A New Global Synthesis. BioScience, 66, 949-964. https://doi.org/10.1093/biosci/biw117

Degefu, F., Mengistu, S., \& Schagerl, M. (2011). Influence of Fish Cage Farming on Water Quality and Plankton in Fish Ponds: A Case Study in the Rift Valley and North Shoa Reservoirs, Ethiopia. Aquaculture, 316, 129-135.

https://doi.org/10.1016/j.aquaculture.2011.03.010

Djihouessi, M. B., Djihouessi, M. B., \& Aina, M. P. (2019). A Review of Habitat and Biodiversity Research in Lake Nokoué, Benin Republic: Current State of Knowledge and Prospects for Further Research. Ecohydrology \& Hydrobiology, 19, 131-145. https://doi.org/10.1016/j.ecohyd.2018.04.003

DPH/MAEP (Direction de la Production Halieutique) (2019). Etat lieux sur l'exploitation des eaux continentales en République du Bénin. (p. 62). Ministère de l'Agriculture, de l'Elevage et de la Pêche du Bénin.

Hagemeijer, E. J. M., Poot, M. J. M., Adjakpa, J. B., \& Coubeou, P. T. (1997). Waterbird 
Survey in the Wetlands of South Benin, 1996 and 1997. SOVON-Onderzoeksrapport.

Jourda, J. P., Kouassi, K. J., Adja, M. G., Deh, S. K., Anani, A. T., Effini, A. T., \& Biemi, J. (2007). Evaluation du degré de protection des eaux souterraines: Vulnérabilité à la pollution de la nappe de Bonoua (Sud-Est de la Côte d'Ivoire) par la méthode DRASTIC. In Acte de conférence Francophone ESRI. Versailles, France.

http://www.esrifrance.fr/sig2007/cocody jourda.htm

Macary, F., Leccia, O., Uny, D., \& Petit, K. (2010). Usage de la géomatique afin de déterminer les zones à risque agroenvironnemental pour la qualité des eaux de surface. In Colloque francophone ESRI(15 p). Versailles, France.

Nfotabong-Atheull, A., Din, N., \& Dahdouh-Guebas, F. (2013). Qualitative and Quantitative Characterization of Mangrove Vegetation Structure and Dynamics in a Peri-Urban Setting of Douala (Cameroon): An Approach Using Air-Borne Imagery. Estuaries and Coasts, 36, 1181-1192. https://doi.org/10.1007/s12237-013-9638-8

Onana, F. M., Togouet, S. Z., Tchatcho, N. N., Teham, H. D., \& Ngassam, P. (2014). Distribution spatio-temporelle du zooplancton en relation avec les facteurs abiotiques dans un hydrosystème urbain: Le ruisseau Kondi (Douala, Cameroun). Journal of Applied Biosciences, 82, 7326-7338. https://doi.org/10.4314/jab.v82i1.6

Rao, S. C., Northup, B. K., Phillips, W. A., \& Mayeux, H. S. (2007). Interseeding Novel Cool-Season Annual Legumes to Improve Bermudagrass Paddocks. Crop Science, 47, 168-173. https://doi.org/10.2135/cropsci2006.02.0088

Roose, E. (1973). Dix-sept années de mesures expérimentales de l'érosion et du ruissellement sur un sol ferrallitique sableux de basse Côte d'Ivoire: Contribution à l'étude de l'érosion hydrique en milieu intertropical. Thèse de Doctorat, Faculté des Sciences, ORSTOM (Office de la recherche scientifique et technique outre-mer), 125.

Roose, E., \& Lelong, F. (1976). Les facteurs de l'érosion hydrique en Afrique Tropicale. Études sur petites parcelles expérimentales de sol. Revue de géographie physique et de géologie dynamique, 18, 365-374.

Saaty, T. L. (1977). A Scaling Method for Priorities in Hierarchical Structures. Journal of Mathematical Psychology, 15, 234-281. https://doi.org/10.1016/0022-2496(77)90033-5

Schoen, R., \& Codvelle, A. (2001). Catagraphie de l'aléa de pollution des eaux superficielles et souteraines par les substances phytosanitaires en région Midi-Pyrénés-Vulnérabilité des eaux souteraines (Rapport BRGM/RP-51456-FR; Richard J., p. 46). BRGM (Bureau de Recherches Géologiques et Minières).

Toyi, M. S., Barima, Y. S. S., Mama, A., André, M., Bastin, J. F., De Cannière, C., Sinsin, B. et al. (2013). Tree Plantation Will Not Compensate Natural Woody Vegetation Cover Loss in the Atlantic Department of Southern Benin. Tropicultura, 31, 62-70.

Yoboue, K. P., Aboua, B. R. D., Berte, S., Coulibaly, J. K., Ouattara, N. I., \& Kouamelan, E. P. (2018). Impacts des exploitations piscicoles en cages flottantes sur la structure des macroinvertébrés benthiques de la lagune Ebrié (Côte d'Ivoire). International Journal of Biological and Chemical Sciences, 12, 769-780. https://doi.org/10.4314/ijbcs.v12i2.12 